\title{
PERAN KEPEMIMPINAN, KUALITAS PELAYANAN PETUGAS PEMUNGUT PAJAK, DAN MOTIVASI WAJIB PAJAK DALAM KEPATUHAN MEMBAYAR PAJAK BUMI DAN BANGUNAN ${ }^{1}$
}

\author{
SUSYANTI \\ TRI UTAMI \\ Universitas Widya Dharma Klaten
}

\begin{abstract}
Abstrak
Pajak Bumi dan Bangunan (PBB) adalah pajak negara yang sebagian besar penerimaannya merupakan pendapatan daerah yang antara lain dipergunakan untuk penyediaan fasilitas yang dinikmati oleh Pemerintah Pusat dan Pemerintah Daerah. Rendahnya nilai realisasi atau penerimaan PBB di daerah pedesaan menjadi latar belakang dalam penelitian ini. Ketertaikan pemilihan sampel yakni Desa Candirejo dikarenakan banyaknya liputan atau pemberitaan media online yang menyatakan Desa Candirejo telah masuk zona merah kemiskinan.

Alat uji hipotesis dalam penelitian ini menggunakan metode analisis regresi berganda. Variabel kepatuhan wajib pajak bumi dan bangunan oleh peneliti dinyatakan sebagai variabel dependen. Sedangkan variabel independennya adalah kepemimpinan kepala desa, kualitas pelayanan petugas pajak (perangkat desa), dan motivasi wajib pajak bumi dan bangunan.

Hasil penelitian menunjukkan bahwa secara parsial pada level $10 \%$ variabel kepemimpinan kepala desa (leadership) berpengaruh signifikan positif terhadap kepatuhan para wajib pajak bumi dan bangunan (obedience). Namun pada level 5\% variabel kepemimpinan kepala desa (leadership) tidak berpengaruh signifikan positif terhadap kepatuhan para wajib pajak bumi dan bangunan (obedience). Sedangkan untuk variabel kualitas pelayanan petugas pemungut $\mathrm{PBB}$ (quality) menunjukkan adanya pengaruh signifikan positif terhadap kepatuhan para wajib pajak bumi dan bangunan (obedience) dan untuk variabel motivasi para wajib pajak bumi dan bangunan (motivation) menunjukkan adanya pengaruh signifikan positif terhadap kepatuhan para wajib pajak bumi dan bangunan (obedience).

Berdasarkan hasil uji simultan menunjukkan bahwa ketiga variabel independen yaitu kepemimpinan kepala desa (leadership), kualitas pelayanan petugas pemungut pajak bumi dan bangunan (quality), dan motivasi para wajib pajak bumi dan bangunan (motivation), secara simultan atau bersama-sama berpengaruh signifikan positif terhadap kepatuhan para wajib pajak bumi dan bangunan (obedience).
\end{abstract}

Kata Kunci: pajak bumi dan bangunan (PBB), kepemimpinan kepala desa (leadership), kualitas (quality) pelayanan petugas pemungut pajak,

\footnotetext{
${ }^{1}$ Susyanti, Tri Utami. 2018. Peran Kepemimpinan, Kualitas Pelayanan Petugas Pemungut Pajak, dan Motivasi Wajib Pajak Dalam Kepatuhan Membayar Pajak Bumi. Jurnal Kiat Bisnis, 6 (4): 318345.
} 
pamong desa, perangkat desa, motivasi (motivation) wajib pajak, kepatuhan (obedience).

\section{Pendahuluan}

Atas dasar Undang-Undang No. 12 Tahun 1985 tentang Pajak Bumi dan Bangunan (PBB) sebagaimana telah diubah dengan Undang-Undang No. 12 Tahun 1994, bahwa Pajak Bumi dan Bangunan adalah pajak negara yang sebagian besar penerimaannya merupakan pendapatan daerah yang antara lain dipergunakan untuk penyediaan fasilitas yang juga dinikmati oleh Pemerintah Pusat dan Pemerintah Daerah. PBB merupakan pajak negara yang dikenakan terhadap objek pajak berupa tanah dan/atau bangunan yang didasarkan pada azas kenikmatan dan manfaat, dan dibayarkan setiap tahunnya. Di dalam perkembangannya, sektor pajak ini yaitu PBB sektor pedesaan dan sektor perkotaan telah menjadi pajak daerah dan diatur di dalam Undang-Undang No. 28 Tahun 2009 tentang Pajak Daerah dan Retribusi Daerah (PDRD) Pasal 77 sampai dengan Pasal 84 dimulai sejak tahun 2010.

Pajak Bumi dan Bangunan merupakan pajak yang menggunakan sistem yang cukup memudahkan bagi wajib pajak dengan sistem pemungutan official assessment system, dimana pihak fiskus lebih pro aktif dan kooperatif melakukan perhitungan, penetapan pajak yang terutang dan mendistribusikannya kepada pemerintah daerah melalui Dispenda berdasarkan Surat Pendaftaran Objek Pajak (SPOP) yang diisi oleh wajib pajak atau verifikasi pihak fiskus di lapangan, Pemerintah daerah melalui Kecamatan, Kelurahan/Desa, bahkan mendistribusikan Surat Pemberitahuan Pajak Terutang (SPPT) sampai ke tangan wajib pajak dan juga menerima pembayaran PBB (Koentarto, 2011:2 dalam Thalib).

Menurut Purenda (2016) dalam liputan situs online Radar Solo (Jawa Pos), di Kabupaten Klaten realisasi penerimaan Pajak Bumi dan Bangunan dari desa dinilai buruk. Penilaian tersebut sesuai dengan nilai total penerimaan pembayaran PBB per 1 Juni 2016 yang diperoleh dari Data System Bank Jateng untuk Kecamatan Ngawen yang hanya sebesar Rp192.549.612,- dari total baku sebesar Rp755.225.549,- Sehingga sisa tagihan PBB yang belum terbayar adalah sebesar 562.675.937,-

Berikut laporan bulanan PBB-P2 Kecamatan Ngawen per 1 Juni 2016.

Tabel 1.1. Laporan Bulanan PBB-P2 Kecamatan Ngawen per 1 Juni 2016.

\begin{tabular}{|c|c|c|c|c|c|c|c|c|c|}
\hline \multicolumn{2}{|c|}{ Desa/Kelurahan } & \multirow[t]{2}{*}{ Baku } & \multirow{2}{*}{$\begin{array}{l}\text { Jmlah } \\
\text { SPT }\end{array}$} & \multicolumn{3}{|c|}{$\begin{array}{c}\text { Pembayaran PBB-P2 } \\
\text { Sampai dengan } 1 \text { Juni } 2016\end{array}$} & \multicolumn{3}{|c|}{ Sisa Tagihan } \\
\hline Kode & Nama & & & SPPT & (Rp) & $(\%)$ & (WP) & (Rp) & (\%) \\
\hline I & II & III & IV & V & VI & VII & VIII & IX & $\mathrm{X}$ \\
\hline 001 & Duwet & 31.890 .917 & 831 & 450 & 15.231 .465 & 47,76 & 381 & 16.659 .452 & 52,24 \\
\hline 002 & Gatak & 45.343 .985 & 1.112 & 748 & 27.523 .669 & 60,70 & 364 & 12.820 .316 & 39,30 \\
\hline 003 & Manjung & 55.977 .402 & 1,493 & 913 & 31.204 .249 & 56,74 & 580 & 24.773 .153 & 44,26 \\
\hline 006 & Kahuman & 57.126 .519 & 1.040 & 311 & 13.504 .846 & 23,64 & 729 & 43.621 .673 & 76,36 \\
\hline 007 & Kwaren & 46.338 .643 & 985 & 103 & 5.033 .777 & 10,86 & 882 & 41.304 .866 & 89,14 \\
\hline 008 & Pepe & 41.609 .524 & 1.216 & 97 & 4.316 .863 & 10,37 & 1.119 & 37.292 .661 & 89.63 \\
\hline 009 & Manjungan & 36.212 .391 & 854 & 430 & 16.023 .529 & 44,25 & 424 & 20.188 .862 & 55,75 \\
\hline
\end{tabular}




\begin{tabular}{|l|l|r|r|r|r|r|r|r|r|}
\hline 010 & Tempursari & 53.884 .857 & 1.175 & 96 & 5.492 .825 & 10,19 & 1.079 & 48.392 .032 & 89,81 \\
\hline 011 & Mayungan & 101.856 .776 & 1.804 & 259 & 11.047 .213 & 10,85 & 1.545 & 90.809 .563 & 89,15 \\
\hline 012 & Candirejo & 66.596 .453 & 1.947 & 401 & 16.495 .295 & 24,77 & 1.546 & 50.101 .158 & 75,23 \\
\hline 013 & Drono & 71.787 .263 & 1.611 & 228 & 8.858 .971 & 12,34 & 1.383 & 62.928 .292 & 87,66 \\
\hline \multicolumn{2}{|c|}{ TOTAL } & $\mathbf{7 5 5 . 2 2 5 . 5 4 9}$ & $\mathbf{1 7 . 2 2 4}$ & $\mathbf{4 . 8 8 4}$ & $\mathbf{1 9 2 . 5 4 9 . 6 1 2}$ & $\mathbf{2 5 , 5 0}$ & $\mathbf{1 2 . 3 4 0}$ & $\mathbf{5 6 2 . 6 7 5 . 9 3 7}$ & $\mathbf{7 4 , 5 0}$ \\
\hline
\end{tabular}

*) Data di atas sesuai dengan Data System Bank Jateng

Rendahnya nilai realisasi PBB sepertinya berimbas pada pembangunanpembangunan infrastruktur yang ada di Kecamatan Ngawen, bahkan khusus untuk Desa Candirejo telah masuk zona merah kemiskinan.

Berdasarkan pemikiran dan uraian data-data di atas, penelitian ini bermaksud menganalisa tentang pengaruh kepemimpinan kepala desa dalam meningkatkan kepatuhan warga selaku wajib pajak dalam memenuhi kewajibannya untuk membayar pajak tepat waktu. Penelitian juga diarahkan untuk mengetahui pengaruh kualitas pelayanan para perangkat desa atau petugas pemungut pajak yang berada dalam pemerintahan desa. Sejauh mana peranan mereka dalam kualitas pelayanan untuk mampu meningkat pendapatan Pajak Bumi dan Bangunan.

Selain pengaruh kepemimpinan dan kualitas pelayanan, peneliti juga tertarik untuk mengetahui pengaruh motivasi para wajib pajak terhadap kepatuhan dalam membayar Pajak Bumi dan Bangunan. Penelitian mengenai faktor-faktor yang disebutkan di atas menyebabkan wajib pajak yang berada di Desa Candirejo Kecamatan Ngawen patuh dalam membayar pajak bumi dan bangunan sebagai wujud atas kewajiban mereka sebagai wajib pajak. Diharapkan pula dengan diketahuinya faktor penyebab kepatuhan wajib pajak dalam membayar pajak maka dapat meningkatkan penerimaan pajak di desa lainnya. Sehingga penelitian ini mengambil judul: "Peran Kepemimpinan, Kualitas Pelayanan Petugas Pemungut Pajak, dan Motivasi Wajib Pajak dalam Kepatuhan Membayar Pajak Bumi dan Bangunan". Penelitian ini terbagi ke dalam 5 bagian. Bagian 1 berisi latar belakang dan tujuan penelitian. Bagian 2 dalam penelitian ini berisi tentang kajian literatur dan pengembangan hipotesis. Bagian 3 mendiskripsikan tentang desain penelitian, yang terdiri dari pemilihan sampel, pengukuran variabel dan alat uji statistik yang digunakan. Bagian 4 menjelaskan tentang hasil penelitian dan bagian 5 menyajikan kesimpulan dan keterbatasan penelitian.

\section{Kajian Literatur dan Pengembangan Hipotesis \\ 2.1 Kepatuhan Wajib Pajak}

Pengertian kepatuhan berasal dari kata dasar patuh, yang berarti disiplin dan taat (Niven, 2002), sedangkan menurut Bastable (2002), kepatuhan adalah istilah yang menjelaskan ketaatan atau pasrah pada tujuan yang telah ditentukan. Patuh yaitu dengan sukarela mengikuti perintah, taat kepada perintah, dan kepatuhan adalah perilaku yang sesuai dengan aturan dan mau berdisiplin.

Dari Wikipedia bahasa Indonesia, kepatuhan (bahasa Inggris: compliance) dalam tata kelola perusahaan, berarti mengikuti suatu spesifikasi, standar, atau hukum yang telah diatur dengan jelas yang biasanya diterbitkan oleh lembaga atau organisasi yang berwenang 
dalam suatu bidang tertentu. Lingkup suatu aturan dapat bersifat internasional maupun nasional, dalam penelitian ini standar atau aturan yang ditetapkan adalah oleh Pemerintah Kabupaten Klaten terkait dengan pelayanan pajak daerah maupun lingkup nasional yaitu pemerintah pusat yaitu Direktorat Jendral Pajak (DJP).

Pajak Bumi dan Bangunan dapat didefinisikan sebagai pajak negara yang dikenakan terhadap bumi dan/atau bangunan berdasarkan Undang-Undang No. 12 Tahun 1985 tentang PBB sebagaimana telah diubah dengan Undang-Undang No. 12 tahun 1994. Subjek PBB adalah orang atau badan yang secara nyata memiliki suatu hak atas bumi, dan/atau memperoleh manfaat atas bumi, dan/atau memiliki, menguasai dan/atau memperoleh manfaat atas bangunan. Dan jika subjek pajak tersebut dikenai wajib membayar pajak maka subjek pajak yang bersangkutan menjadi wajib pajak.

Menurut Muljono (2010) wajib pajak bumi dan bangunan adalah subjek pajak yang dikenakan kewajiban membayar pajak menurut Undang-undang PBB. Dalam hal ini suatu obyek pajak belum jelas diketahui wajib pajaknya. Sehingga Direktur Jenderal Pajak dapat menetapkan subyek pajaknya. Menurut Mardiasmo (2011), dasar pengenaan pajak Bumi dan Bangunan adalah Nilai Jual Objek Pajak (NJOP). Besarnya NJOP ditetapkan setiap tiga tahun oleh Kantor Wilayah Direktorat Jendral Pajak atas nama Menteri Keuangan dengan mempertimbangkan pendapat Gubenur/Bupati/Walikota (Pemerintah Daerah) setempat.

Kartasapoetra dkk (1989) dalam Thalib (2013) berpendapat tentang manfaat Pajak Bumi dan Bangunan (PBB) yaitu khusus dalam pengguna hasil penerima $\mathrm{PBB}$ oleh pemerintah diarahkan kepada tujuan untuk kepentingan masyarakat di daerah yang bersangkutan, terutama dalam pembangunan sarana berbagai kepentingan umum/masyarakat, seperti perbaikan atau pengadaan jalan dan jembatan daerah, pengadaan dan perbaikan pasar, pengadaan dan perbaikan sarana pendidikan dan banyak lagi sarana lainnya yang berkaitan dengan kepentingan umum yang dikelola oleh pemerintah daerah.

Menurut Safri Nurmanto dalam Siti Kurnia Rahayu (2010) mengatakan bahwa kepatuhan perpajakan dapat didefinisikan sebagai suatu keadaaan dimana wajib pajak memenuhi semua kewajiban perpajakan dan melaksanakan hak perpajakannya. Pendapat E. Ellyani (1989) yang dikutip Kiryanto (1998), kepatuhan wajib pajak didefinisikan sebagai memasukkan dan melaporkan pada waktunya informasi yang diperlukan, mengisi secara benar jumlah pajak yang terutang, dan membayar pajak pada waktunya, tanpa ada tindakan pemaksaan. Ketidakpatuhan timbul jika ada salah satu syarat definisi tersebut tidak dipenuhi.

Serupa dengan pendapat Norman D. Nowak (Moh. Zain: 2004), kepatuhan wajib pajak memiliki pengertian yaitu suatu iklim kepatuhan dan kesadaran pemenuhan kewajiban perpajakan, tercermin dalam 
situasi di mana wajib pajak paham atau berusaha untuk memahami semua ketentuan peraturan perundang-undangan perpajakan; mengisi formulir pajak dengan lengkap dan jelas; menghitung jumlah pajak yang terutang dengan benar; dan membayar pajak yang terutang tepat pada waktunya.

Kepatuhan wajib pajak bumi dan bangunan meliputi perilaku wajib pajak dalam membayar PBB tepat waktu, melaporkan setiap bentuk perubahan dari tanah/rumah yang ditempati sendiri ataupun tanah/rumah yang ditempati tetangga, mengurus dan mengisi surat Pemberitahuan Objek Pajak (SPOP) dengan benar, serta menyerahkan SPOP yang sudah terisi ke kantor pelayanan PBB atau aparat yang ditunjuk.

Variabel kepatuhan wajib pajak bumi dan bangunan akan menjadi variabel dependen (dependent variable) dalam penelitian ini. Variabel dependen adalah variabel yang dijelaskan atau dipengaruhi oleh variabel independen (independent variable). Sedangkan pengertian variabel independen adalah variabel yang mempengaruhi/menjadi penyebab berubahnya/timbulnya variabel dependen atau variabel terkait.

\subsection{Kepemimpinan dan Kepatuhan Wajib Pajak}

Menurut wikipedia bahasa Indonesia, kepemimpinan adalah proses memengaruhi atau memberi contoh oleh pemimpin kepada pengikutnya dalam upaya mencapai tujuan organisasi (Nurkolis, 2003). Faktor Kepemimpinan dalam menimbulkan kepatuhan wajib pajak dapat diartikan sebagai proses memengaruhi para wajib pajak dalam upaya mencapai tujuan yaitu terlunasinya besaran nominal pajak bumi dan bangunan yang terutang. Kepemimpinan adalah kegiatan untuk mempengaruhi perilaku orang lain, atau seni mempengaruhi perilaku manusia baik perorangan maupun kelompok (Thoha, 1995 dalam Fachrizal, 2013:169). Pada hakikatnya kepemimpinan memiliki pengertian yang lebih luas apabila dibanding dengan manajemen (Thoha, 2001). Dengan kata lain, kepemimpinan dapat terjadi dimana saja, asalkan seseorang menunjukkan kemampuanya mempengaruhi perilaku orang lain kearah tercapainya suatu tujuan tertentu. Sedangkan manajemen merupakan jenis pemikiran yang khusus dari kepemimpinan didalam usahanya mencapai tujuan organisasi yang terikat dengan tata krama birokrasi atau ketentuan-ketentuan organisasi dan terikat dengan jalur komunikasi struktural.

Tannenbaum, Wescler, dan Massarik (dalam Winardi, 1997) menyimpulkan bahwa kepemimpinan sebagai pengaruh antara pribadi yang dijalankan dalam suatu situasi tertentu, serta diarahkan melalui proses komunikasi, kearah pencapaian satu atau beberapa tujuan tertentu. Apabila dikaitkan dengan kepemimpinan kepada desa dalam mencapai kepatuhan wajib pajak, dalam hal ini adalah warga desa agar 
patuh (bersedia) membayar besarnya nominal pajak bumi dan bangunan yang terutang.

Kepemimpinan kepala desa dalam memberikan pengaruh kepada wargannya akan menjadi variabel independen pertama dalam penelitian ini sehingga dapat diambil hipotesis sebagai berikut:

$\mathrm{H}_{1}$ : Terdapat pengaruh positif signifikan antara kepemimpinan kepala desa terhadap peningkatan kepatuhan wajib pajak bumi dan bangunan di Desa Candirejo Kecamatan Ngawen Kabupaten Klaten.

\subsection{Kualitas Pelayanan dan Kepatuhan Wajib Pajak}

Pengertian pelayanan menurut Kotler (2002) adalah setiap tindakan atau kegiatan yang dapat ditawarkan oleh suatu pihak kepada pihak lain, yang pada dasarnya tidak berwujud dan tidak mengakibatkan kepemilikan apapun. Sedangkan kata kualitas meliputi suatu usaha untuk memenuhi atau melebihkan harapan pelanggan. Kualitas juga dapat mencakup produk, jasa, manusia, proses dan lingkungan serta merupakan kondisi yang selalu berubah.

Dengan mengadopsi pengertian Kotler tersebut terkait definisi tentang kualitas dan pelayanan dapat diambil kesimpulan bahwa kualitas pelayanan adalah segala bentuk aktivitas yang dilakukan oleh pemerintah desa guna memenuhi harapan warga desa selaku wajib pajak. Pelayanan dalam hal ini diartikan sebagai jasa atau service yang disampaikan oleh pemilik jasa yang berupa kemudahan, kecepatan, hubungan, kemampuan dan keramahtamahan yang ditujukan melalui sikap dan sifat dalam memberikan pelayanan untuk kepuasan wajib pajak. Kualitas pelayanan (service quality) dapat diketahui dengan cara membandingkan persepsi para wajib pajak atas pelayanan yang nyatanyata mereka terima/peroleh dengan pelayanan yang sesungguhnya mereka harapkan/inginkan terhadap atribut-atribut pelayanan suatu perusahaan.

Dengan adanya pemahaman tersebut, peneliti ingin mengetahui pengaruh kualitas pelayanan para perangkat desa atau petugas pemungut pajak yang berada dalam pemerintahan desa yang diharapkan mampu mendorong peningkatan besarnya jumlah penerimaan pajak bumi dan bangunan. Kualitas pelayanan para perangkat desa atau petugas pemungut pajak yang berada dalam pemerintahan desa akan menjadi variabel independen kedua dalam penelitian ini sehingga dapat diambil hipotesis sebagai berikut:

$\mathrm{H}_{2}$ : Terdapat pengaruh positif signifikan antara kualitas pelayanan para perangkat desa atau petugas pemungut pajak yang berada dalam pemerintahan desa terhadap peningkatan kepatuhan wajib pajak bumi dan bangunan di Desa Candirejo Kecamatan Ngawen Kabupaten Klaten. 


\subsection{Motivasi dan Kepatuhan Wajib Pajak}

Mitchell (1997) menjabarkan pengertian motivasi merupakan proses yang menjelaskan intensitas, arah, dan ketekunan seorang individu untuk mencapai tujuannya. Berbeda dengan motivasi dalam pengertian yang berkembang di masyarakat yang seringkali disamakan dengan semangat. Sehingga, perlu dipahami bahwa ada perbedaan penggunaan istilah motivasi di masyarakat. Sebagian masyarakat mengartikan motivasi sebagai suatu alasan, dan sebagian lain mengartikan motivasi sama halnya dengan semangat.

Motivasi menurut Uno (2007) dapat diartikan sebagai dorongan internal dan eksternal dalam diri seseorang yang diindikasikan dengan adanya; hasrat dan minat; dorongan dan kebutuhan; harapan dan citacita; penghargaan dan penghormatan.

Teori mengenai motivasi juga dapat dikaitan dengan teori penentuan tujuan, yaitu teori yang mengemukakan bahwa niat untuk mencapai tujuan merupakan sumber motivasi kerja yang utama (Locke, 1968). Artinya, tujuan memberitahu seorang apa yang harus dilakukan dan berapa banyak usaha yang harus dikeluarkan (Early, 1987).

Selain dua hipotesis di atas, penelitian ini juga berfokus pada pengaruh motivasi para wajib pajak terhadap kepatuhan dalam membayar Pajak Bumi dan Bangunan. Sehingga hipotesis ketiga dapat diambil sebagai berikut:

$\mathrm{H}_{3}$ : Terdapat pengaruh positif signifikan antara motivasi warga desa selaku wajib pajak terhadap peningkatan kepatuhan wajib pajak bumi dan bangunan di Desa Candirejo Kecamatan Ngawen Kabupaten Klaten.

\section{Metode Penelitian}

\subsection{Data dan Sampel}

Dalam penelitian ini, jenis data yang digunakan adalah data kuantitatif. Data kuantitatif adalah data yang diukur dalam suatu skala numerik (Kuncoro, 2003, hal 213). Dan dinyatakan dalam skala interval yaitu data yang diukur dengan jarak di antara dua titik yang sudah diketahui. Data kuantitatif digunakan untuk mengukur data dari pertanyaan kuesioner.

Penelitian ini menggunakan sumber data primer dan data sekunder. Data primer diperoleh dari responden dengan mengisi serta menjawab item-item pertanyaan dalam kuesioner melalui sesi tanya jawab (interview) maupun mandiri dimana responden menjawab dengan mengisi (menyilang/melingkari) sendiri jawaban-jawaban atas pertanyaan-pertanyaan yang ada dalam kuesioner. Sedangkan data sekunder diperoleh dari studi literatur dan penelitian sebelumnya.

Penelitian ini menggunakan purposive sampling yaitu prosedur untuk mendapatkan unit sampel menurut tujuan penelitian (Kuncoro, 2003). Sampel dipilih berdasarkan tujuan peneliti, yaitu warga desa 
Candirejo Kecamatan Ngawen yang menjadi wajib pajak bumi dan bangunan.

\subsection{Pengukuran Variabel}

\subsubsection{Validitas dan Reliabilitas Instrumen Penelitian}

Penelitian ini menggunakan data angket atau kuesioner untuk mengumpulkan data dari responden yang diukur dengan skala likert 5 poin. Sebuah penelitian empiris akan dapat dilakukan dengan baik jika data dikumpulkan dengan instrumen yang berkualitas. Kualitas instrumen tersebut ditunjukkan oleh validitas dan reliabilitasnya.

Pengukuran validitas dilakukan dengan teknik korelasi product moment pearson untuk mengetahui sejauh mana ketepatan dan kecermatan suatu alat ukur dalam melakukan fungsi ukurnya. Ukuran kevalidan dapat dilihat dari correlation pearson skor total yang memiliki korelasi signifikan 0.05 dan 0.01 .

Uji Reliabilitas dilakukan untuk menguji derajat kebebasan pengukuran dari kesalahan random dan karenanya menghasilkan bentuk yang konstan, atau dengan kata lain dilakukan untuk melihat apakah alat ukur yang digunakan konsisten atau tidak. Teknik pengujian adalah dengan menggunakan alat uji cronbach's alpha.

\subsubsection{Asumsi Klasik}

Pengujian normalitas dapat dilakukan dengan uji KolmogorovSmirnov. Jika probabilitas lebih besar daripada alpha $(\alpha)$ maka asumsi normalitas terpenuhi. Selain pengujian normalitas, peneliti juga akan melakukan uji multikolinieritas untuk menguji apakah dalam model regresi ditemukan adanya korelasi antar variabel independen. Untuk mendeteksi ada tidaknya multikolinieritas dapat dilakukan dengan melihat nilai toleransi (tolerance value) dan nilai variansce inflation factor (VIF). Nilai yang umumnya dipakai adalah tolerance lebih kecil daripada 0.10 dan nilai VIF diatas 10 . Jika uji multikolinieritas menghasilkan nilai tolerance lebih kecil daripada 0.10 dan nilai VIF di atas 10 , maka menunjukkan adanya multikolinieritas dan sebaliknya.

Pengujian autokorelasi bertujuan untuk menguji apakah model regresi yang digunakan ada korelasi antara kesalahan pengganggu pada periode $\mathrm{t}$ dengan periode $\mathrm{t}-1$ (periode sebelumnya). Cara mendeteksi ada dan tidaknya autokorelasi, dilakukan uji Durbin-Watson (DW test). Jika nilai DW terletak antara $d_{U}$ dan $\left(4-d_{U}\right)$ berarti tidak ada autokorelasi.

Pengujian heteroskedastisitas bertujuan untuk menguji apakah dalam model regresi terjadi ketidaksamaan varians dari residualnya satu pengamatan ke pengamatan lainnya atau varians 
antar variabel independen tidak sama. Untuk menguji adanya heteroskedastisitas dapat dilakukan uji glejser, yaitu meregresikan nilai absolute residual terhadap variabel independen (Gujarati, 1995). Apabila variabel independen secara stastistik tidak signifikan mempengaruhi variabel dependen atau apabila nilai signifikansinya lebih besar daripada alpha (0.05), maka tidak terjadi heteroskedastisitas. Terdapatnya heteroskedastisitas dalam model regresi banyak ditemukan pada data crossection. Dalam penelitian ini menggunakan data tersebut. Untuk mengatasi masalah heteroskedastisitas tersebut dapat dilakukan dengan transformasi logaritma pada setiap variabel, baik independen maupun dependen (Ghozali, 2001). Namun dikarenakan penelitian ini bukan merupakan penelitian ekonometri (tidak melibatkan angka-angka rasio maupun angka nominal yang berdigit banyak, seperti dalam penelitian keuangan) maka hal tersebut tidak peneliti lakukan. Selain penelitian ini merupakan penelitian ilmu sosial yang melibatkan perilaku, juga dikarenakan jawaban yang diberikan atas respon dari kuesioner atas suatu perilaku merupakan jawaban yang bersifat subjektif.

\subsection{Model Pengujian Statistik}

Model pengujian hipotesis dalam penelitian ini menggunakan metode analisis regresi berganda. Model regresi dalam penelitian ini adalah sebagai berikut:

Obedience $=a+b_{1}$ Leadership $+b_{2}$ Quality $+b_{3}$ Motivation $+e$

Keterangan model:

\begin{tabular}{|c|c|}
\hline Obedience & $=$ Kepatuhan Wajib Pajak \\
\hline Leadership & $=$ Kepemimpinan \\
\hline Quality & $=$ Kualitas Pelayanan \\
\hline Motivation & $=$ Motivasi \\
\hline$a$ & $=$ intercept \\
\hline$b$ & $=$ slope \\
\hline$e$ & $=$ error \\
\hline
\end{tabular}

\section{Analisis Data dan Pembahasan}

\subsection{Analisis Deskriptif}

Dalam penelitian ini mengunakan data kuesioner dengan menggunakan purposive sampling, dimana yang menjadi responden adalah warga desa Candirejo Kecamatan Ngawen yang menjadi wajib pajak bumi dan bangunan. Dalam kuesioner responden ditanyakan mengenai statistik demografi yang berkaitan dengan responden. Sehingga perlu sekiranya untuk dilakukan analisis deskriptif untuk mengetahui gambaran dari responden. 
Dalam analisis ini, digunakan sebanyak 53 responden dari 55 responden yang mengembalikan kuesioner. Dua kuesioner yang lain tidak dapat digunakan sebagai sampel dikarenakan setelah melalui proses editing data, kuesioner tersebut tidak terisi dengan lengkap. Berikut gambaran proses pengumpulan data kuesioner:

Tabel 4.1. Gambaran proses pengumpulan data kuesioner

\begin{tabular}{lrc}
\hline \hline Kuesioner yang disebarkan & 60 & buah \\
Kuesioner yang kembali & 55 & buah \\
Kuesioner yang tidak valid & 2 & buah \\
Kuesioner yang valid & 53 buah \\
Persentase pengembalian & 91.67 persen \\
Persentase kuesioner valid & 88.33 persen \\
\hline \hline
\end{tabular}

Dengan demikian kuesioner yang dianalisis dalam penelitian ini memiliki response rate yang sangat bagus.

Dalam analisis deskriptif untuk karakteristik responden dapat dilihat dari demografi responden, yaitu: umur, jenis kelamin, jabatan, tingkat pendidikan terakhir. Selain dari demografi responden, juga ditanyakan mengenai pernah/tidak mengikuti sosialisasi dan penyuluhan tentang Pajak Bumi dan Bangunan serta opini tentang tingkat masalah mengenai kepatuhan terhadap pajak bumi dan bangunan yang terjadi dewasa ini. Hasil data demografi responden, dapat dipaparkan dalam tabel-tabel berikut:

Tabel 4.2. Kategori usia responden

\begin{tabular}{|l|r|r|}
\hline \multicolumn{1}{|c|}{ Kategori Usia } & Jumlah & \multicolumn{2}{c|}{ Persentase } \\
\hline Kurang dari 30 tahun & 2 & $3,77 \%$ \\
\hline $31-40$ tahun & 14 & $26,42 \%$ \\
\hline $41-50$ tahun & 18 & $33,96 \%$ \\
\hline $51-60$ tahun & 13 & $24,53 \%$ \\
\hline Lebih dari 60 tahun & 6 & $11,32 \%$ \\
\hline
\end{tabular}

Tabel 4.3. Jenis kelamin

\begin{tabular}{|l|r|r|}
\hline \multicolumn{1}{|c|}{ Jenis Kelamin } & Jumlah & \multicolumn{1}{c|}{ Persentase } \\
\hline Laki-laki & 38 & $71,70 \%$ \\
\hline Perempuan & 15 & $28,30 \%$ \\
\hline
\end{tabular}

Tabel 4.4. Pendidikan terakhir

\begin{tabular}{|l|r|r|}
\hline \multicolumn{1}{|c|}{ Kategori Usia } & Jumlah & \multicolumn{1}{c|}{ Persentase } \\
\hline Non gelar & 50 & $94,34 \%$ \\
\hline Sarjana (S1) & 3 & $5,66 \%$ \\
\hline Pasca Sarjana & 0 & $0,00 \%$ \\
\hline
\end{tabular}

Tabel 4.5. Jenis Pekerjan

\begin{tabular}{|l|r|r|}
\hline \multicolumn{1}{|c|}{ Jenis Pekerjaan } & Jumlah & \multicolumn{1}{c|}{ Persentase } \\
\hline Buruh & 25 & $47,17 \%$ \\
\hline Petani & 4 & $7,55 \%$ \\
\hline Karyawan Swasta & 3 & $5,66 \%$ \\
\hline PNS/Pegawai/Guru & 1 & $1,89 \%$ \\
\hline Wiraswasta & 11 & $20,75 \%$ \\
\hline
\end{tabular}




\begin{tabular}{|l|r|r|}
\hline Ibu Rumah Tangga & 7 & $13,21 \%$ \\
\hline Pengangguran & 2 & $3,77 \%$ \\
\hline
\end{tabular}

Tabel 4.6. Kepemilikan NPWP

\begin{tabular}{|l|r|r|}
\hline \multicolumn{1}{|c|}{ Kepemilikan NPWP } & Jumlah & Persentase \\
\hline Memiliki & 23 & $43,40 \%$ \\
\hline Belum/Tidak Memiliki & 30 & $56,60 \%$ \\
\hline
\end{tabular}

Tabel 4.7. Sosialisasi/Penyuluhan Pajak Bumi dan Bangunan

\begin{tabular}{|l|r|r|}
\hline Sosialisasi/Penyuluhan & Jumlah & \multicolumn{1}{|c|}{ Persentase } \\
Pajak Bumi dan Bangunan & & $13,21 \%$ \\
\hline Pernah mendapat & 7 & $86,79 \%$ \\
\hline Belum pernah mendapat & 46 & \\
\hline
\end{tabular}

Terkait jenis pekerjaan responden didominasi oleh para kaum buruh. Jenis pekerjaan berikutnya diduduki oleh wiraswasta, ibu rumah tangga, petani, karyawan swasta, pengangguran, dan guru. Mengenai kegiatan sosialisasi dan penyuluhan tentang pajak bumi dan bangunan, sebagian besar warga yang menjadi responden mengaku belum pernah memperoleh atau menghadiri kegiatan tersebut. Dari 53 responden hanya ada 7 responden yang mengaku pernah memperoleh kegiatan sosialisasi maupun penyuluhan tersebut. Responden ditanya mengenai perhatian mereka terhadap masalah-masalah kepatuhan dalam membayar pajak bumi dan bangunan. Pertanyaan ini kemungkinan bias dikarenakan mereka menilai perhatian diri mereka sendiri. Responden dianjurkan memilih skala antara 1 sampai dengan 7, dengan skala dari yang terendah hingga tertinggi. Hasil skala tersebut menunjukkan bahwa rata-rata penilaian responden adalah 7 dengan kisaran 50,94\%, dan diurutan kedua responden menjawab 5 dengan kisaran 30,19\%.

Tabel 4.8. Tanggapan Responden terhadap Masalah Kepatuhan Membayar Pajak Bumi dan Bangunan

\begin{tabular}{|c|r|r|}
\hline $\begin{array}{c}\text { Tanggapan Responden } \\
\text { terhadap kepatuhan PBB }\end{array}$ & Jumlah & \multicolumn{1}{c|}{ Persentase } \\
\hline Tidak penting 1 & 0 & $0.00 \%$ \\
\hline 2 & 0 & $0.00 \%$ \\
\hline 3 & 1 & $1,89 \%$ \\
\hline 4 & 4 & $7,55 \%$ \\
\hline 5 & 16 & $30,19 \%$ \\
\hline 6 & 5 & $9,43 \%$ \\
\hline Sangat Penting 7 & 27 & $50,94 \%$ \\
\hline
\end{tabular}

\subsection{Uji Validitas dan Reliabilitas Instrumen Penelitian}

\subsubsection{Hasil Uji Validitas Instrumen Penelitian}

Pengukuran validitas dilakukan dengan teknik korelasi product moment pearson untuk mengetahui sejauh mana ketepatan dan kecermatan suatu alat ukur dalam melakukan fungsi ukurnya. Ukuran kevalidan dapat dilihat dari correlation 
pearson skor total yang memiliki korelasi signifikan 0.05 dan 0.01 .

Dari hasil validitas didapati bahwa untuk item pertanyaanpertanyaan variabel kepemimpinan dapat dikatakan valid atau signifikan karena nilainya kurang dari 0,05 $(<0,05)$.

Tabel 4.9. Hasil Uji Validitas Variabel Kepemimpinan

\begin{tabular}{|c|c|c|}
\hline & & leadTot \\
\hline Lead1 & $\begin{array}{l}\text { Pearson Correlation } \\
\text { Sig. (2-tailed) } \\
\mathrm{N}\end{array}$ & $\begin{array}{r}.305 \\
.026 \\
53\end{array}$ \\
\hline Lead2 & $\begin{array}{l}\text { Pearson Correlation } \\
\text { Sig. (2-tailed) } \\
\mathrm{N}\end{array}$ & $\begin{array}{r}.494^{* *} \\
.000 \\
53 \\
\end{array}$ \\
\hline Lead3 & $\begin{array}{l}\text { Pearson Correlation } \\
\text { Sig. (2-tailed) } \\
\mathrm{N}\end{array}$ & $\begin{array}{r}.864^{* *} \\
.000 \\
53 \\
\end{array}$ \\
\hline Lead4 & $\begin{array}{l}\text { Pearson Correlation } \\
\text { Sig. (2-tailed) } \\
\mathrm{N}\end{array}$ & $\begin{array}{r}.516^{*} \\
.000 \\
53 \\
\end{array}$ \\
\hline Lead5 & $\begin{array}{l}\text { Pearson Correlation } \\
\text { Sig. (2-tailed) } \\
\mathrm{N}\end{array}$ & $\begin{array}{r}.677^{* *} \\
.000 \\
53 \\
\end{array}$ \\
\hline Lead6 & $\begin{array}{l}\text { Pearson Correlation } \\
\text { Sig. (2-tailed) } \\
\text { N }\end{array}$ & $\begin{array}{r}.826 \\
.000 \\
53 \\
\end{array}$ \\
\hline Lead7 & $\begin{array}{l}\text { Pearson Correlation } \\
\text { Sig. (2-tailed) } \\
\mathrm{N}\end{array}$ & $\begin{array}{r}.824^{* *} \\
.000 \\
53 \\
\end{array}$ \\
\hline Lead8 & $\begin{array}{l}\text { Pearson Correlation } \\
\text { Sig. (2-tailed) } \\
\mathrm{N}\end{array}$ & $\begin{array}{r}.771^{*} \\
.000 \\
53 \\
\end{array}$ \\
\hline Lead9 & $\begin{array}{l}\text { Pearson Correlation } \\
\text { Sig. (2-tailed) } \\
\mathrm{N}\end{array}$ & $\begin{array}{r}.800^{* *} \\
.000 \\
53\end{array}$ \\
\hline Lead10 & $\begin{array}{l}\text { Pearson Correlation } \\
\text { Sig. (2-tailed) } \\
\mathrm{N}\end{array}$ & $\begin{array}{r}.808^{* *} \\
.000 \\
53\end{array}$ \\
\hline leadTot & $\begin{array}{l}\text { Pearson Correlation } \\
\text { Sig. (2-tailed) } \\
\text { N }\end{array}$ & 53 \\
\hline
\end{tabular}


Sedangkan dari hasil validitas untuk variabel kualitas pelayanan petugas dan atau pemungut pajak bumi dan bangunan ditemukan bahwa untuk pertanyaan item 2 dapat dinyatakan tidak valid karena nilainya lebih dari 0,05 (> 0,05). Sehingga untuk pengujian selanjutnya item pertanyaan tersebut tidak dapat digunakan.

Tabel 4.10. Hasil Uji Validitas Variabel Kualitas Pelayanan (Quality)

\begin{tabular}{|c|c|c|}
\hline & & QualTot \\
\hline Qual1 & $\begin{array}{l}\text { Pearson Correlation } \\
\text { Sig. (2-tailed) } \\
\mathrm{N}\end{array}$ & $\begin{array}{r}.630^{* *} \\
.000 \\
53\end{array}$ \\
\hline Qual2 & $\begin{array}{l}\text { Pearson Correlation } \\
\text { Sig. (2-tailed) } \\
\text { N }\end{array}$ & $\frac{.226}{53}$ \\
\hline Qual3 & $\begin{array}{l}\text { Pearson Correlation } \\
\text { Sig. (2-tailed) } \\
\text { N }\end{array}$ & $\begin{array}{r}.658^{* *} \\
.000 \\
53\end{array}$ \\
\hline Qual4 & $\begin{array}{l}\text { Pearson Correlation } \\
\text { Sig. (2-tailed) } \\
\mathrm{N}\end{array}$ & $\begin{array}{r}.866 * \\
.000 \\
53 \\
\end{array}$ \\
\hline Qual5 & $\begin{array}{l}\text { Pearson Correlation } \\
\text { Sig. (2-tailed) } \\
\mathrm{N}\end{array}$ & $\begin{array}{r}.886^{*} \\
.000 \\
53 \\
\end{array}$ \\
\hline Qual6 & $\begin{array}{l}\text { Pearson Correlation } \\
\text { Sig. (2-tailed) } \\
\mathrm{N}\end{array}$ & $\begin{array}{r}.944^{* *} \\
.000 \\
53 \\
\end{array}$ \\
\hline Qual7 & $\begin{array}{l}\text { Pearson Correlation } \\
\text { Sig. (2-tailed) } \\
\mathrm{N}\end{array}$ & $\begin{array}{r}.800^{* *} \\
.000 \\
53\end{array}$ \\
\hline Qual8 & $\begin{array}{l}\text { Pearson Correlation } \\
\text { Sig. (2-tailed) } \\
\text { N }\end{array}$ & $\begin{array}{r}.743^{* *} \\
.000 \\
53\end{array}$ \\
\hline Qual9 & $\begin{array}{l}\text { Pearson Correlation } \\
\text { Sig. (2-tailed) } \\
\mathrm{N}\end{array}$ & $\begin{array}{r}.862^{* *} \\
.000 \\
53\end{array}$ \\
\hline Qual10 & $\begin{array}{l}\text { Pearson Correlation } \\
\text { Sig. (2-tailed) } \\
\mathrm{N}\end{array}$ & $\begin{array}{r}.808^{*} \\
.000 \\
53\end{array}$ \\
\hline QualTot & $\begin{array}{l}\text { Pearson Correlation } \\
\text { Sig. (2-tailed) } \\
\mathrm{N}\end{array}$ & 1 \\
\hline
\end{tabular}


Tabel 4.11. Hasil Uji Ulang terhadap Validitas Variabel Kualitas Pelayanan (Quality), setelah mengeluarkan item penyataan yang tidak valid (Qual2)

\begin{tabular}{|c|c|c|}
\hline & & QualTot_2 \\
\hline Qual1 & $\begin{array}{l}\text { Pearson Correlation } \\
\text { Sig. (2-tailed) } \\
\mathrm{N}\end{array}$ & $\begin{array}{r}.680^{* *} \\
.000 \\
53\end{array}$ \\
\hline Qual3 & $\begin{array}{l}\text { Pearson Correlation } \\
\text { Sig. (2-tailed) } \\
\mathrm{N}\end{array}$ & $\begin{array}{r}.602^{* *} \\
.000 \\
53 \\
\end{array}$ \\
\hline Qual4 & $\begin{array}{l}\text { Pearson Correlation } \\
\text { Sig. (2-tailed) } \\
\text { N }\end{array}$ & $\begin{array}{r}.882^{* *} \\
.000 \\
53\end{array}$ \\
\hline Qual5 & $\begin{array}{l}\text { Pearson Correlation } \\
\text { Sig. (2-tailed) } \\
\mathrm{N}\end{array}$ & $\begin{array}{r}.885^{\star \star} \\
.000 \\
53\end{array}$ \\
\hline Qual6 & $\begin{array}{l}\text { Pearson Correlation } \\
\text { Sig. (2-tailed) } \\
\mathrm{N} \\
\end{array}$ & $\begin{array}{r}.956 * \\
.000 \\
53\end{array}$ \\
\hline Qual7 & $\begin{array}{l}\text { Pearson Correlation } \\
\text { Sig. (2-tailed) } \\
\mathrm{N}\end{array}$ & $\begin{array}{r}.784^{\star *} \\
.000 \\
53\end{array}$ \\
\hline Qual8 & $\begin{array}{l}\text { Pearson Correlation } \\
\text { Sig. (2-tailed) } \\
\mathrm{N}\end{array}$ & $\begin{array}{r}.760^{* *} \\
.000 \\
53 \\
\end{array}$ \\
\hline Qual9 & $\begin{array}{l}\text { Pearson Correlation } \\
\text { Sig. (2-tailed) } \\
\mathrm{N}\end{array}$ & $\begin{array}{r}.897^{* *} \\
.000 \\
53\end{array}$ \\
\hline Qual10 & $\begin{array}{l}\text { Pearson Correlation } \\
\text { Sig. (2-tailed) } \\
\mathrm{N}\end{array}$ & $\begin{array}{r}.856^{* *} \\
.000 \\
53 \\
\end{array}$ \\
\hline QualTot_2 & $\begin{array}{l}\text { Pearson Correlation } \\
\text { Sig. (2-tailed) } \\
\mathrm{N}\end{array}$ & 1 \\
\hline
\end{tabular}

Dalam uji validitas instrumen penelitian, hal serupa juga dialami oleh variabel motivasi, dimana ditemukan item pertanyaan yang tidak valid, yaitu item 4 (Motiv4) karena nilainya lebih dari $0,05(>0,05)$. Oleh karenanya untuk pengujian selanjutnya item pertanyaan tersebut tidak akan digunakan. 
Tabel 4.12. Hasil Uji Validitas Variabel Motivasi (Motivation)

\begin{tabular}{|c|c|c|}
\hline & & MotivTot \\
\hline \multirow[t]{3}{*}{ Motiv1 } & Pearson Correlation & $.710^{\star \star}$ \\
\hline & Sig. (2-tailed) & .000 \\
\hline & $\mathrm{N}$ & 53 \\
\hline \multirow[t]{3}{*}{ Motiv2 } & Pearson Correlation & $.796^{* *}$ \\
\hline & Sig. (2-tailed) & .000 \\
\hline & $\mathrm{N}$ & 53 \\
\hline \multirow[t]{3}{*}{ Motiv3 } & Pearson Correlation & $.789^{\star \star}$ \\
\hline & Sig. (2-tailed) & .000 \\
\hline & $\mathrm{N}$ & 53 \\
\hline \multirow[t]{3}{*}{ Motiv4 } & Pearson Correlation & .235 \\
\hline & Sig. (2-tailed) & \\
\hline & $\mathrm{N}$ & 53 \\
\hline \multirow[t]{3}{*}{ Motiv5 } & Pearson Correlation & $.496^{* *}$ \\
\hline & Sig. (2-tailed) & .000 \\
\hline & $\mathrm{N}$ & 53 \\
\hline \multirow[t]{3}{*}{ Motiv6 } & Pearson Correlation & $.736^{* *}$ \\
\hline & Sig. (2-tailed) & .000 \\
\hline & $\mathrm{N}$ & 53 \\
\hline \multirow[t]{3}{*}{ Motiv7 } & Pearson Correlation & $.686^{\star *}$ \\
\hline & Sig. (2-tailed) & .000 \\
\hline & $\mathrm{N}$ & 53 \\
\hline \multirow[t]{3}{*}{ Motiv8 } & Pearson Correlation & $.695^{\star \star}$ \\
\hline & Sig. (2-tailed) & .000 \\
\hline & $\mathrm{N}$ & 53 \\
\hline \multirow[t]{3}{*}{ Motiv9 } & Pearson Correlation & $.728^{\star *}$ \\
\hline & Sig. (2-tailed) & .000 \\
\hline & $\mathrm{N}$ & 53 \\
\hline \multirow[t]{3}{*}{ Motiv10 } & Pearson Correlation & $.711^{\star \star}$ \\
\hline & Sig. (2-tailed) & .000 \\
\hline & $\mathrm{N}$ & 53 \\
\hline \multirow[t]{3}{*}{ MotivTot } & Pearson Correlation & 1 \\
\hline & Sig. (2-tailed) & \\
\hline & $\mathrm{N}$ & 53 \\
\hline
\end{tabular}


Tabel 4.13. Hasil Uji Ulang terhadap Validitas Variabel Motivasi (Motivation), setelah mengeluarkan item penyataan yang tidak valid (Motiv4)

\begin{tabular}{|c|c|c|}
\hline & & MotivTot_2 \\
\hline Motiv1 & $\begin{array}{l}\text { Pearson Correlation } \\
\text { Sig. (2-tailed) } \\
\mathrm{N}\end{array}$ & $\begin{array}{r}.709^{* *} \\
.000 \\
53\end{array}$ \\
\hline Motiv2 & $\begin{array}{l}\text { Pearson Correlation } \\
\text { Sig. (2-tailed) } \\
\mathrm{N}\end{array}$ & $\begin{array}{r}.825^{\star *} \\
.000 \\
53 \\
\end{array}$ \\
\hline Motiv3 & $\begin{array}{l}\text { Pearson Correlation } \\
\text { Sig. (2-tailed) } \\
\mathrm{N}\end{array}$ & $\begin{array}{r}.800^{\star *} \\
.000 \\
53\end{array}$ \\
\hline Motiv5 & $\begin{array}{l}\text { Pearson Correlation } \\
\text { Sig. (2-tailed) } \\
\mathrm{N}\end{array}$ & $\begin{array}{r}.403^{* *} \\
.003 \\
53\end{array}$ \\
\hline Motiv6 & $\begin{array}{l}\text { Pearson Correlation } \\
\text { Sig. (2-tailed) } \\
\mathrm{N}\end{array}$ & $\begin{array}{r}.729^{* \star} \\
.000 \\
53 \\
\end{array}$ \\
\hline Motiv7 & $\begin{array}{l}\text { Pearson Correlation } \\
\text { Sig. (2-tailed) } \\
\mathrm{N}\end{array}$ & $\begin{array}{r}.768^{\star *} \\
.000 \\
53\end{array}$ \\
\hline Motiv8 & $\begin{array}{l}\text { Pearson Correlation } \\
\text { Sig. (2-tailed) } \\
\mathrm{N}\end{array}$ & $\begin{array}{r}.768^{\star *} \\
.000 \\
53\end{array}$ \\
\hline Motiv9 & $\begin{array}{l}\text { Pearson Correlation } \\
\text { Sig. (2-tailed) } \\
\mathrm{N}\end{array}$ & $\begin{array}{r}.800^{\star *} \\
.000 \\
53\end{array}$ \\
\hline Motiv10 & $\begin{array}{l}\text { Pearson Correlation } \\
\text { Sig. (2-tailed) } \\
\mathrm{N}\end{array}$ & $\begin{array}{r}.770^{\star \star} \\
.000 \\
53\end{array}$ \\
\hline MotivTot_2 & $\begin{array}{l}\text { Pearson Correlation } \\
\text { Sig. (2-tailed) } \\
\mathrm{N}\end{array}$ & 53 \\
\hline
\end{tabular}

Sedangkan pengujian validitas untuk variabel kepatuhan dapat dinyatakan bahwa semua item dalam pertanyaan tersebut adalah valid karena nilainya kurang dari $0,05(<0,05)$. 
Tabel 4.14. Hasil Uji Validitas Variabel Kepatuhan (Obedience)

\begin{tabular}{|ll|r|}
\hline & & ObeTot \\
\hline Obe1 & Pearson Correlation & $.868^{* *}$ \\
& Sig. (2-tailed) & .000 \\
& $\mathrm{~N}$ & 53 \\
\hline Obe2 & Pearson Correlation & $.841^{* *}$ \\
& Sig. (2-tailed) & .000 \\
& $\mathrm{~N}$ & 53 \\
\hline Obe3 & Pearson Correlation & $.938^{* *}$ \\
& Sig. (2-tailed) & .000 \\
& $\mathrm{~N}$ & 53 \\
\hline Obe4 & Pearson Correlation & $.917^{*}$ \\
& Sig. (2-tailed) & .000 \\
& $\mathrm{~N}$ & 53 \\
\hline Obe5 & Pearson Correlation & $.891^{* *}$ \\
& Sig. (2-tailed) & .000 \\
& $\mathrm{~N}$ & 53 \\
\hline ObeTot & Pearson Correlation & 1 \\
& Sig. (2-tailed) & \\
& $\mathrm{N}$ & 53 \\
\hline
\end{tabular}

\subsubsection{Hasil Uji Reliabilitas Instrumen Penelitian}

Uji reliabilitas dilakukan untuk menguji derajat kebebasan pengukuran dari kesalahan random dan karenanya menghasilkan bentuk yang konstan, atau dengan kata lain dilakukan untuk melihat apakah alat ukur yang digunakan konsisten atau tidak. Teknik pengujian adalah dengan menggunakan alat uji cronbach's Alpha.

Dari masing-masing variabel menghasilkan nilai cronbach's Alpha diatas 0.7. Berikut tabel-tabelnya.

Tabel 4.15. Hasil Uji Reliabilitas Variabel Kepemimpinan (Leadership)

Reliability Statistics

\begin{tabular}{|r|r|}
\hline Cronbach's Alpha & N of Items \\
\hline .885 & \\
\hline
\end{tabular}

Tabel 4.16. Hasil Uji Reliabilitas Variabel Kualitas Pelayanan (Quality)

Reliability Statistics

Cronbach's Alpha $\quad \mathrm{N}$ of Items

.935 
Tabel 4.17. Hasil Uji Reliabilitas Variabel Motivasi

(Motivation)

Reliability Statistics

\begin{tabular}{|r|l|}
\hline Cronbach's Alpha & N of Items \\
\hline .876 & \\
\hline
\end{tabular}

Tabel 4.18. Hasil Uji Reliabilitas Variabel Kepatuhan (Obedience)

Reliability Statistics

\begin{tabular}{|r|r|}
\hline Cronbach's Alpha & N of Items \\
\hline .932 & \\
\hline
\end{tabular}

\subsection{Uji Confirmatory Factor Analysis}

Uji confirmatory factor analysis, sebuah pengujian untuk melihat seberapa ideal suatu model regresi dapat terbentuk dengan beberapa variabel yang seharusnya digunakan. Sebelum uji analisis faktor dilakukan, harus diketahui terlebih dulu nilai KMO (Kaiser-MeyerOlkin). Jika nilai KMO lebih dari 0,5 dan sig < 0,05. Artinya, dapat dilanjut untuk melakukan pengecekan berapa variabel yang dapat terbentuk dalam suatu model. Berikut adalah tabelnya.

Tabel 4.19. Hasil Uji KMO (Kaiser-Meyer-Olkin)

KMO and Bartlett's Test

\begin{tabular}{|l|r|}
\hline Kaiser-Meyer-Olkin Measure of Sampling Adequacy. \\
Bartlett's Test of $\quad$ Approx. Chi-Square \\
Sphericity & Df \\
& Sig.
\end{tabular}

Tabel 4.20. Hasil Uji Confirmatory Factor Analysis

\begin{tabular}{|c|c|c|c|c|c|c|}
\hline \multirow[b]{2}{*}{ Component } & \multicolumn{3}{|c|}{ Initial Eigenvalues } & \multicolumn{3}{|c|}{ Extraction Sums of Squared Loadings } \\
\hline & Total & $\begin{array}{c}\% \text { of } \\
\text { Variance }\end{array}$ & $\begin{array}{c}\text { Cumulative } \\
\%\end{array}$ & Total & $\begin{array}{c}\% \text { of } \\
\text { Variance }\end{array}$ & $\begin{array}{c}\text { Cumulative } \\
\%\end{array}$ \\
\hline 1 & 11.835 & 35.862 & 35.862 & 11.835 & 35.862 & 35.862 \\
\hline 2 & 8.636 & 26.170 & 62.033 & 8.636 & 26.170 & 62.033 \\
\hline 3 & $2.437 \mid$ & 7.386 & 69.419 & 2.437 & 7.386 & 69.419 \\
\hline 4 & 1.680 & 5.091 & 74.510 & 1.680 & 5.091 & 74.510 \\
\hline 5 & 172 & 3.551 & 78.061 & 1.172 & 3.551 & 78.061 \\
\hline 6 & .998 & 3.024 & 81.085 & & & \\
\hline 7 & .940 & 2.848 & 83.933 & & & \\
\hline 8 & 848 & 2.570 & 86.502 & & & \\
\hline 9 & .697 & 2.112 & 88.614 & & & \\
\hline 10 & .587 & 1.779 & 90.393 & & & \\
\hline 11 & .509 & 1.543 & 91.936 & & & \\
\hline 12 & .474 & 1.438 & 93.373 & & & \\
\hline 13 & .384 & 1.162 & 94.535 & & & \\
\hline 14 & .353 & 1.069 & 95.604 & & & \\
\hline 15 & .275 & .833 & 96.437 & & & \\
\hline 16 & .247 & .748 & 97.186 & & & \\
\hline
\end{tabular}




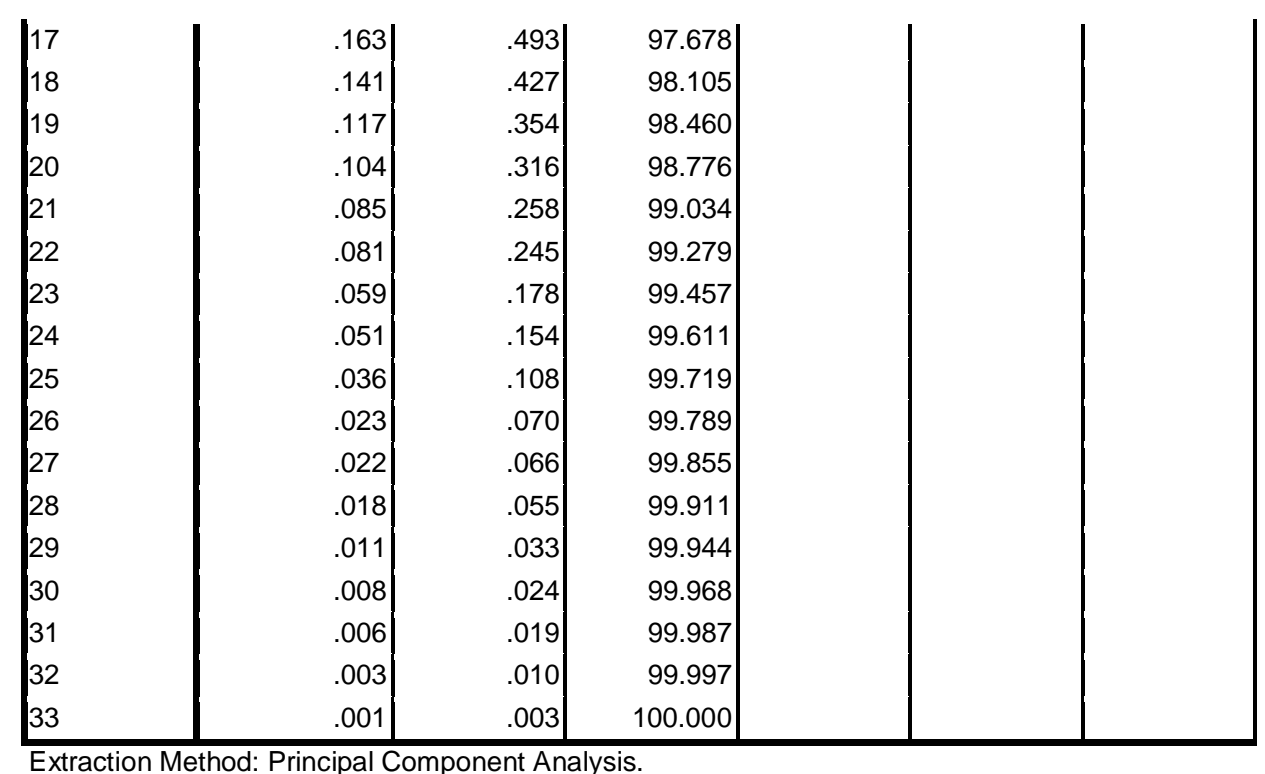

Extraction Method: Principal Component Analysis.

Tabel 4.21. Hasil Uji Confirmatory Factor Analysis yang Layak Menjadi Variabel dalam Penelitian ini

Rotated Component Matrix

\begin{tabular}{|c|c|c|c|c|c|}
\hline & \multicolumn{5}{|c|}{ Component } \\
\hline & 1 & 2 & 3 & 4 & 5 \\
\hline Lead1 & -.079 & .412 & .421 & .522 & -.172 \\
\hline Lead2 & .015 & .476 & .246 & .654 & .169 \\
\hline Lead3 & .861 & -.064 & -.013 & .290 & .226 \\
\hline Lead4 & .096 & .200 & .250 & .693 & .117 \\
\hline Lead5 & .305 & -.001 & -.122 & .784 & -.006 \\
\hline Lead6 & .668 & -.042 & -.035 & .400 & .373 \\
\hline Lead7 & .602 & .098 & -.141 & .555 & -.057 \\
\hline Lead8 & .928 & .029 & -.140 & .062 & .010 \\
\hline Lead9 & .779 & -.105 & -.028 & .321 & .028 \\
\hline Lead10 & .824 & .043 & -.077 & .264 & -.064 \\
\hline Qual1 & .725 & .075 & -.084 & -.173 & -.088 \\
\hline Qual3 & .440 & .542 & .214 & -.225 & .428 \\
\hline Qual4 & .804 & -.011 & -.018 & -.039 & .465 \\
\hline Qual5 & .790 & .056 & .087 & .088 & .395 \\
\hline Qual6 & .929 & .031 & .111 & -.032 & .154 \\
\hline Qual7 & .676 & -.166 & .375 & .031 & .326 \\
\hline Qual8 & .787 & -.081 & .259 & .165 & -.040 \\
\hline Qual9 & .897 & -.182 & -.056 & .088 & .104 \\
\hline Qual10 & .917 & -.040 & -.082 & -.149 & -.143 \\
\hline Motiv1 & .334 & .423 & .596 & -.166 & -.131 \\
\hline Motiv2 & -.195 & .249 & .861 & .079 & .125 \\
\hline Motiv3 & -.191 & .191 & .883 & -.013 & .177 \\
\hline Motiv5 & .686 & .465 & -.016 & .089 & .189 \\
\hline Motiv6 & .000 & .277 & .688 & .180 & -.075 \\
\hline Motiv7 & -.065 & .879 & .262 & .159 & -.099 \\
\hline Motiv8 & -.203 & .888 & .207 & .036 & .048 \\
\hline Motiv9 & -.123 & .860 & .313 & .164 & -.010 \\
\hline Motiv10 & -.142 & .801 & .224 & .253 & .254 \\
\hline
\end{tabular}




\begin{tabular}{|c|c|c|c|c|c|}
\hline Obe1 & -.066 & .488| & .637| & |.064 & .317 \\
\hline Obe2 & .277 & .425 & .352 & .185 & .530 \\
\hline Obe3 & .314 & .510 & .585 & |137. & .293 \\
\hline Obe4 & .264 & .598 & .492 & -.020 & .466 \\
\hline Obe5 & .298 & .467 & .426 & |198. & .564 \\
\hline
\end{tabular}

Dari 3 tabel di atas dapat ditarik suatu kesimpulan bahwa dalam penelitian ini, jika model telah ideal seharusnya terdiri dari dari 4 variabel, yaitu 3 variabel independen (kepemimpinan, kualitas pelayanan, motivasi) dan 1 variabel dependen (kepatuhan). Namun berdasarkan jawaban yang diberikan oleh para responden, setelah dilakukan uji confirmatory factor analysis, diperoleh suatu model yang dapat dikatakan ideal dengan 5 variabel, seperti yang ditunjukkan dalam Tabel 4.18.

Meskipun demikian tujuan dari penelitian ini akan tetap fokus kepada variabel-variabel yang akan diujikan. Menurut Tabel 4.19, variabel-variabel yang layak ada di dalam penelitian ini adalah sebagai berikut:

1. Variabel Kepemimpinan Kepala Desa (Leadership), terdiri dari item pertanyaan nomor 1, 2, 4, 5,6, dan 7 .

2. Variabel Kualitas Pelayanan Petugas Pemungut Pajak, terdiri dari item pertanyaan nomor $1,3,4,5,6,7,8,9$, dan 10 .

3. Variabel Motivasi para Wajib Pajak Bumi dan Bangunan, terdiri dari item pertanyaan nomor 1, 2, 3, dan 6 .

4. Variabel Kepatuhan para Wajib Pajak Bumi dan Bangunan, terdiri dari item pertanyaan nomor 1, 2, 3, 4, dan 5. Atau, dapat dikatakan semua item pertanyaan dalam variabel kepatuhan adalah layak untuk digunakan dalam penelitian.

\subsection{Uji Asumsi Klasik}

\subsubsection{Hasil Uji Normalitas}

Pengujian normalitas dilakukan dengan uji KolmogorovSmirnov. Jika probabilitas lebih besar daripada alpha $(\alpha)$ maka asumsi normalitas terpenuhi karena Asymp. Sig > 0,05.

Tabel 4.22. Hasil Uji Normalitas

One-Sample Kolmogorov-Smirnov Test

\begin{tabular}{|ll|r|}
\hline & & $\begin{array}{c}\text { Unstandardized } \\
\text { Residual }\end{array}$ \\
\hline Normal Parameters & \\
& Mean & Std. Deviation \\
Most Extreme Differences & Absolute & .0000000 \\
& Positive & 2.07929746 \\
& Negative & .119 \\
Kolmogorov-Smirnov Z & & .094 \\
Asymp. Sig. (2-tailed) & & -.119 \\
a. Test distribution is Normal. & .869 \\
\hline
\end{tabular}




\subsubsection{Hasil Uji Multikolinieritas}

Uji multikolinieritas bertujuan untuk menguji apakah dalam model regresi ditemukan adanya korelasi antar variabel independen. Untuk mendeteksi ada tidaknya multikolinieritas dapat dilakukan dengan melihat nilai toleransi (tolerance value) dan nilai variansce inflation factor (VIF). Nilai yang umumnya dipakai adalah tolerance lebih kecil daripada 0.10 dan nilai VIF diatas 10. Jika uji multikolinieritas menghasilkan nilai tolerance lebih kecil daripada 0.10 dan nilai VIF di atas 10, maka menunjukkan adanya multikolinieritas dan sebaliknya. Tabel berikut ini tidak menunjukkan adanya multikoninieritas dalam model regresi, karena nilai VIF $<10$.

Tabel 4.23. Hasil Uji Multikolinieritas

\begin{tabular}{|c|c|c|c|}
\hline \multirow{2}{*}{\multicolumn{2}{|c|}{ Model }} & \multicolumn{2}{|c|}{ Collinearity Statistics } \\
\hline & & Tolerance & VIF \\
\hline \multirow[t]{4}{*}{1} & (Constant) & & \\
\hline & LEAD & .757 & 1.320 \\
\hline & QUAL & .780 & 1.282 \\
\hline & MOT & .964 & 1.037 \\
\hline
\end{tabular}

\subsubsection{Hasil Uji Autokorekasi}

Uji autokorelasi bertujuan untuk menguji apakah model regresi yang digunakan ada korelasi antara kesalahan pengganggu pada periode $\mathrm{t}$ dengan periode $\mathrm{t}-1$ (periode sebelumnya). DurbinWatson (DW test) dapat mendeteksi ada dan tidaknya autokorelasi. Jika nilai DW terletak antara $\mathrm{d}_{\mathrm{U}}$ dan $\left(4-\mathrm{d}_{\mathrm{U}}\right)$ berarti tidak ada autokorelasi. Dari tabel berikut tidak terjadi autokorelasi karena nilai DW 1,544 > dari batas atas 1,506

Tabel 4.24. Hasil Uji Autokorekasi

\begin{tabular}{|c|c|}
\hline Model & Durbin-Watson \\
\hline 1 & 1.544 \\
\hline
\end{tabular}

\subsubsection{Hasil Uji Heteroskedastisitas}

Pengujian heteroskedastisitas bertujuan untuk menguji apakah dalam model regresi terjadi ketidaksamaan varians dari residualnya satu pengamatan ke pengamatan lainnya atau varians antar variabel independen tidak sama. Untuk menguji adanya heteroskedastisitas dapat dilakukan uji glejser, yaitu meregresikan nilai absolute residual terhadap variabel independen (Gujarati, 1995). Apabila variabel independen secara stastistik tidak signifikan mempengaruhi variabel dependen atau apabila nilai signifikansinya lebih besar daripada alpha (0.05), maka tidak terjadi heteroskedastisitas. 
Tabel 4.25. Hasil Uji Heteroskedastisitas

\begin{tabular}{|c|c|c|c|c|c|c|}
\hline \multirow{2}{*}{\multicolumn{2}{|c|}{ Model }} & \multicolumn{2}{|c|}{$\begin{array}{c}\text { Unstandardized } \\
\text { Coefficients }\end{array}$} & \multirow{2}{*}{\begin{tabular}{|c|}
$\begin{array}{c}\text { Standardized } \\
\text { Coefficients }\end{array}$ \\
Beta \\
\end{tabular}} & \multirow[b]{2}{*}{$t$} & \multirow[b]{2}{*}{ Sig. } \\
\hline & & B & Std. Error & & & \\
\hline \multirow[t]{4}{*}{1} & (Constant) & 5.399 & 1.415 & & 3.815 & .000 \\
\hline & LEAD & -.075 & .061 & -.174 & -1.231 & .224 \\
\hline & QUAL & .014 & .030 & .067 & .478 & .635 \\
\hline & MOT & -.176 & .048 & -.459 & -3.666 & .001 \\
\hline
\end{tabular}

Berdasarkan hasil uji heteroskedastisitas pada tabel di atas dapat disimpulkan bahwa masih terdapat heteroskedastisitas pada variabel motivasi, karena nilai Sig. $<0,05$. Terdapatnya heteroskedastisitas dalam model regresi banyak ditemukan pada data crossection. Dalam penelitian ini menggunakan data tersebut. Untuk mengatasi masalah heteroskedastisitas tersebut dapat dilakukan dengan transformasi logaritma pada setiap variabel, baik independen maupun dependen (Ghozali, 2001). Namun dikarenakan penelitian ini bukan merupakan penelitian ekonometri (tidak melibatkan angka-angka rasio maupun angka nominal yang berdigit banyak, seperti dalam penelitian keuangan) maka hal tersebut tidak peneliti lakukan. Selain penelitian ini merupakan penelitian ilmu sosial yang melibatkan perilaku, juga dikarenakan jawaban yang diberikan atas respon dari kuesioner atas suatu perilaku merupakan jawaban yang bersifat subjektif.

\subsection{Pengujian Hipotesis}

\subsubsection{Hasil Uji Parsial}

Hasil uji parsial menunjukkan bahwa pada level $10 \%$ variabel kepemimpinan kepala desa (leadership) berpengaruh signifikan positif terhadap kepatuhan para wajib pajak bumi dan bangunan (obedience). Ini artinya hipotesis pertama, $\mathrm{H}_{1}$ terdukung. Namun pada level 5\% variabel kepemimpinan kepala desa (leadership) tidak berpengaruh signifikan positif terhadap kepatuhan para wajib pajak bumi dan bangunan (obedience). Ini artinya hipotesis tersebut, $\mathrm{H}_{1}$ tidak terdukung.

Sedangkan untuk variabel kualitas pelayanan petugas pemungut pajak bumi dan bangunan (quality) menunjukkan adanya pengaruh signifikan positif terhadap kepatuhan para wajib pajak bumi dan bangunan (obedience), yang artinya hipotesis kedua, $\mathrm{H}_{2}$ terdukung.

Untuk variabel motivasi para wajib pajak bumi dan bangunan (motivation) menunjukkan adanya pengaruh signifikan positif terhadap kepatuhan para wajib pajak bumi dan bangunan (obedience), yang artinya hipotesis ketiga, $\mathrm{H}_{3}$ terdukung. 
Tabel 4.26. Hasil Uji Parsial

\begin{tabular}{|c|c|c|c|c|c|c|}
\hline \multirow{2}{*}{\multicolumn{2}{|c|}{ Model }} & \multicolumn{2}{|c|}{$\begin{array}{l}\text { Unstandardized } \\
\text { Coefficients }\end{array}$} & \multirow{2}{*}{\begin{tabular}{|c|}
$\begin{array}{c}\text { Standardized } \\
\text { Coefficients }\end{array}$ \\
Beta \\
\end{tabular}} & \multirow[b]{2}{*}{$\mathrm{T}$} & \multirow[b]{2}{*}{ Sig. } \\
\hline & & B & Std. Error & & & \\
\hline \multirow[t]{4}{*}{1} & (Constant) & 3.684 & 2.400 & & 1.535 & .131 \\
\hline & LEAD & .199 & .104 & .200 & 1.918 & .061 \\
\hline & QUAL & .119 & .051 & .240 & 2.334 & .024 \\
\hline & MOT & .543 & .082 & .617 & 6.659 & .000 \\
\hline
\end{tabular}

a. Dependent Variable: OBE

\subsubsection{Hasil Uji Simultan}

Berdasarkan hasil uji simultan menunjukkan bahwa ketiga variabel independen yaitu kepemimpinan kepala desa (leadership), kualitas pelayanan petugas pemungut pajak bumi dan bangunan (quality), dan motivasi para wajib pajak bumi dan bangunan (motivation), secara simultan atau bersama-sama berpengaruh signifikan positif terhadap kepatuhan para wajib pajak bumi dan bangunan (obedience).

Tabel 4.27. Hasil Uji Simultan (Uji F)

ANOVA $^{\mathrm{b}}$

\begin{tabular}{|l|r|r|r|c|c|}
\hline Model & Sum of Squares & Df & Mean Square & $\mathrm{F}$ & Sig. \\
\hline 1 Regression & 330.047 & 3 & 110.016 & 23.978 & $.000^{\mathrm{a}}$ \\
Residual & 224.821 & 49 & 4.588 & & \\
Total & 554.868 & 52 & & & \\
\hline
\end{tabular}

a. Predictors: (Constant), MOT, QUAL, LEAD

b. Dependent Variable: OBE

Jika melihat nilai Adjusted $R$ Square sebesar 0,57. Ini berarti pengaruh variabel independen terhadap variabel dependen sebesar $57 \%$, sedangkan sisanya $43 \%$ dipengaruhi oleh variabel lain yang tidak diteliti dalam model ini.

Tabel 4.28. Hasil Uji Simultan (Adjusted R Square)

Model Summary ${ }^{b}$

\begin{tabular}{|l|r|r|r|r|r|}
\hline Model & $\mathrm{R}$ & R Square & $\begin{array}{c}\text { Adjusted R } \\
\text { Square }\end{array}$ & $\begin{array}{c}\text { Std. Error of } \\
\text { the Estimate }\end{array}$ & $\begin{array}{c}\text { Durbin- } \\
\text { Watson }\end{array}$ \\
\hline 1 & $.771^{\mathrm{a}}$ & .595 & .570 & 2.14200 & 1.544 \\
\hline
\end{tabular}

a. Predictors: (Constant), MOT, QUAL, LEAD

b. Dependent Variable: OBE

\section{Simpulan dan Saran}

\subsection{Simpulan}

Penelitian ini bertujuan untuk menganalisa tentang pengaruh kepemimpinan kepala desa dalam meningkatkan kepatuhan warga 
selaku wajib pajak dalam memenuhi kewajibannya untuk membayar pajak tepat waktu. Penelitian juga diarahkan untuk mengetahui pengaruh kualitas pelayanan para perangkat desa atau petugas pemungut pajak yang berada dalam pemerintahan desa. Sejauh mana peranan mereka dalam kualitas pelayanan untuk mampu meningkat pendapatan Pajak Bumi dan Bangunan. Selain itu, penelitian juga bertujuan untuk mengetahui pengaruh motivasi para wajib pajak terhadap kepatuhan dalam membayar Pajak Bumi dan Bangunan.

Setelah dilakukan analisis dari hasil pengujian seperti yang disajikan pada halaman sebelumnya, dapat ditarik beberapa kesimpulan sebagai berikut:

1. Kepala Desa Candirejo selaku pamong tertinggi di tingkat pemerintahan desa memiliki pengaruh dalam meningkatkan kepatuhan warga desa Candirejo selaku wajib pajak dalam memenuhi kewajibannya untuk membayar pajak bumi dan bangunan tepat pada waktunya.

2. Kualitas pelayanan para perangkat desa atau petugas pemungut pajak yang berada dalam pemerintahan desa mampu memberikan pengaruh kepada wajib pajak untuk meningkatkan kepatuhan dalam membayar pajak bumi dan bangunan sebelum jatuh tempo.

3. Pemberian motivasi bagi para wajib pajak mampu meningkatkan tingkat kepatuhan warga desa dalam membayar Pajak Bumi dan Bangunan.

4. Hasil penelitian secara simultan tidak dapat menolak hipotesis. Hal ini berarti bahwa kepatuhan wajib pajak yaitu warga desa Candirejo yang memiliki atau tercatat sebagai wajib pajak bumi dan bangunan, dalam membayar pajak bumi dan bangunan dipengaruhi secara signifikan oleh faktor kepemimpinan kepala desa (leadership), kualitas pelayanan petugas pemungut pajak bumi dan bangunan (quality), dan motivasi para wajib pajak bumi dan bangunan (motivation).

\subsection{Keterbatasan Penelitian}

Dalam setiap penelitian tentunya memiliki beberapa keterbatasanketerbatasan yang dimiliki terkait dengan instrumen penelitian yang digunakan oleh peneliti. Penelitian ini pun memiliki beberapa keterbatasan sebagai berikut:

1. Sampel yang digunakan dalam penelitian adalah warga desa Candirejo yang tercatat sebagai wajib pajak bumi dan bangunan. Sehingga untuk generalisasi hasil penelitian ini harus diintepretasikan dengan hati-hati.

2. Penelitian ini hanya menguji kepatuhan dan variabel-variabel yang mempengaruhinya. Dimana variabel-variabel tersebut perlu dikembangkan lebih lanjut jika ingin dilakukan penelitian lanjutan.

3. Pemahaman mengenai variabel-variabel dalam penelitian ini masih sangat luas, sehingga pengertian kepatuhan dan variabel-variabel lainnya dapat menjadi ambigu. 
4. Untuk mendapat pemahaman yang lengkap mengenai kegiatan apa yang dilakukan dan hal-hal apa saja yang dapat dilakukan oleh warga desa agar dapat berpartisipasi secara penuh sesuai porsinya dalam peningkatan pendapatan daerah tidak cukup hanya mengetahui variabel kepatuhan dan variabel-variabel dalam penelitian ini. Tetapi juga diperlukan sosialisasi dan penyuluhan yang merata kepada warga desa, agar apa yang menjadi agenda pemerintah desa maupun daerah dapat tercapai melalui pendanaan dari pajak bumi dan bangunan.

\subsection{Saran}

Penelitian ini diharapkan dapat menjadi masukan dan bahan pertimbangan bagi para pamong desa selaku pejabat yang duduk di pemerintahan desa untuk dapat memberikan pengaruh positif kepada warga desa untuk patuh dan bersedia memenuhi kewajibannya membayar pajak bumi dan bangunan. Namun demikian, melihat keterbatasan-keterbatasan yang ada, maka perlu dilakukan penelitian lanjutan untuk memperbaiki maupun mengembangkan penelitian ini. Saran dan rekomendasi yang dapat peneliti sebutkan adalah sebagai berikut:

1. Usaha kepala desa dalam mengupayakan kepatuhan warga desa perlu untuk lebih ditingkatkan atau dimaksimalkan. Karena hanya sebagian kecil warga yang mengetahui perihal sosialisasi maupun penyuluhan yang dilakukan oleh pemerintah desa terkait pajak bumi dan bangunan.

2. Penelitian dalam bidang perpajakan mapun perilaku-perilaku yang mempengaruhi wajib pajak dapat terus dilakukan dengan mempertimbangkan berbagai informasi tentang peraturan-peraturan perpajakan yang berlaku.

3. Penelitian selanjutnya dapat membuat instrumen yang lebih baik dari yang telah ada saat ini dengan memasukkan variabel-variabel lain yang mampu mendukung hipotesis.

4. Warga desa selaku wajib pajak bumi dan bangunan seyogyanya dapat memiliki perspektif yang lebih baik untuk taat dan tertib dalam membayar pajak, yaitu bahwa pajak yang dibayarkan oleh masyarakat akan dimaksimalkan untuk pembangunan sarana dan prasarana desa maupun daerah.

\section{DAFTAR PUSTAKA}

Bastable, Susan B, 2002. Peran Perawat Sebagai Pendidik. Buku Kedokteran EGC, Jakarta.

Data System Bank Jateng, 2016. Laporan Bulanan PBB-P2 Kecamatan Ngawen per 1 Juni 2016. Reporting. Kabupaten Klaten.

Early, 1987. Task Planning and Energy Expended: Exploration of How Goals Influence Performance. Jurnal Psikologi. 
Fachrizal, Muhammad, 2013. Kepemimpinan Lurah dalam Meningkatkan Kinerja Pegawai. Jurnal Pemerintahan Integratif, (1): 14:26.

Ghozali, Imam, 2001. Aplikasi Analisis Multivariate dengan Program SPSS. Badan Penerbit Universitas Diponegoro, Semarang.

Gujarati, Damodar, 1995. Basic Econometrics. McGraw Hill International Editions, New York.

Kartasapoetra dkk, 1989. Pajak Bumi dan Bangunan, Prosedur dan Pelaksanaannya. Bina Aksara, Jakarta.

Kiryanto, 2000. Analisis Pengaruh Penerapan Struktur Pengendalian Intern Terhadap Kepatuhan Wajib Pajak Badan dalam Memenuhi Kewajiban Pajak Penghasilannya. Ekobis, Vol. 1 No. 1, p. 41-52.

Koentarto, Ilham, 2011. Analisis Faktor-Faktor yang Mempengaruhi Kepatuhan Masyarakat dalam Melakukan Pembayaran Pajak Bumi dan Bangunan. Jurnal. Kotawarigin Barat.

Kotler, Philip, 2002. Manajemen Pemasaran 1. Millineum ed. PT Prenhallindo, Jakarta.

Kuncoro, Mudrajad. 2003. Metode Riset Untuk Bisnis dan Ekonomi. Penerbit Erlangga, Jakarta.

Locke, E. A., 1968. Toward a Theory of Task Motivation and Incentive, Organizational Behavior and Human Performance.

Mardiasmo, 2011. Perpajakan. Edisi Revisi. Andi, Jakarta.

Mitchell, T. R., 1997. Research in Organizational Behavior. CT: JAI Press Greenwich.

Muljono, Djoko, 2010. Panduan Brevet Pajak-PPN, PPn.BM, Bea Materai, PBB, BPHTB. CV. Andi Offset, Yogyakarta.

Niven, Neil, 2002. Psikologi Kesehatan: Pengantar untuk Perawat \& Profesional Kesehatan Lain. EGC, Jakarta.

Nurkolis, 2003. Manajemen Berbasis Sekolah: Teori, MOdel dan Aplikasi. Grasindo.

Purenda, Angga, 2016. Realisasi PBB dari Desa Buruk. Article. Situs www.radarsolo.jawapos.com.

Rahayu, Siti Kurnia, 2010. Perpajakan Indonesia. Edisi Pertama. Graha Ilmu, Yogyakarta.

Robbins, Stephen P.; Judge, Timothy A., 2008. Perilaku Organisasi Buku 1. Salemba Empat, Jakarta.

Thalib, Gustin, 2013. Identifikasi Faktor-Faktor yang Mempengaruhi Kepatuhan Wajib Pajak dalam Melakukan Pembayaran Pajak Bumi Dan Bangunan Di

Kecamatan Kota Timur Kota Gorontalo. Skripsi. Universitas Negeri Gorontalo.

Thoha, Mifta, 2001. Kepemimpinan dalam Manajemen, suatu Pendekatan Perilaku. Grafindo Persada, Jakarta Raja.

Undang-Undang Nomor 12 Tahun 1985. Pajak Bumi dan Bangunan (PBB). Direktorat Jendral Pajak Kementerian Keuangan.

Undang-Undang Nomor 12 Tahun 1994. Perubahan atas Undang-Undang Nomor 12 Tahun 1985 tentang Pajak Bumi dan Bangunan (PBB). Direktorat Jendral Pajak Kementerian Keuangan. 
Undang-Undang Nomor 28 Tahun 2009. Pajak Daerah dan Retribusi Daerah (PDRD). Direktorat Jendral Pajak Kementerian Keuangan.

Uno, Hamzah B., 2008. Teori Motivasi dan Pengukurannya. Bumi Aksara, Jakarta.

Winardi, 1997. Kepemimpinan dalam Manajemen. PT. Rineka Cipta, Jakarta.

Zain, Mohammad, 2004. Manajemen Perpajakan. Salemba Empat, Jakarta. 